\title{
Forecasting Groundwater Level in an Arid Area According to Climatic Data
}

\author{
Khurshidbek Makhmudov, Yasuhiro Mitani, Tetsuya Kusuda \\ Department of Civil Engineering, Graduate School of Engineering, Kyushu University, Fukuoka, Japan \\ Email: xurshid@doc.kyushu-u.ac.jp
}

Received 9 March 2015; accepted 29 April 2015; published 5 May 2015

Copyright (C 2015 by authors and Scientific Research Publishing Inc.

This work is licensed under the Creative Commons Attribution International License (CC BY). http://creativecommons.org/licenses/by/4.0/

c) (7) Open Access

\begin{abstract}
Development of a prediction method on groundwater level in a river basin depending on climatic data is the purpose of this study. The bases of the prediction method are water balance calculation, transient filtering an interpolation method on climatic data developed by the authors. Development of a method for predicting groundwater level depending on precipitation, abstraction and so on was carried out using the simulation model MIKE SHE. In order to demonstrate the results of this study, topographic maps and the geographic information system (GIS) were used. The calibrated predictive values of the groundwater level were compared with actual data measured in observation wells. As a result, the values of the root-mean-squared error in the calculated points are less than 0.66 .
\end{abstract}

\section{Keywords}

Groundwater, Precipitation, Interpolation, Calibration, GIS

\section{Introduction}

As it is known, areas with an arid climate with groundwater runoff determine the main conditions of crop production [1]. In establishing mode of an irrigation plants, especially cotton, the state of groundwater determines the amount of water-supply via irrigation canals. Soil, affected by salt and in the presence of groundwater toxic salts can give condition of groundwater, which determines the main conditions of plant life, for example: a small distance from the ground surface leads to salinization and soil degradation, and causes a deep state of increased demand for irrigation water [2]. Prediction of ground water regime is a scientific challenge. The challenge is caused by the presence of a variety of factors that affect the groundwater regime; the most influential of them are precipitation and runoff [3]. At the same time, the groundwater regime has a significant impact to the area. In this regard, the object of research was established in the Chirchik river basin area in the Tashkent region of 
Uzbekistan (Figure 1). As a subject research, primarily influence of precipitation was determined in conjunction with other components of the water balance of a river basin in groundwater areas. The objectives of this paper are to predict the ground water regime in the region with less groundwater observation wells. Also the results of the prediction are applicable to protect soil from erosion and soil salinization.

\section{Materials and Methods}

The target area of research is the area of Chirchik river basin, where crop production is carried out exclusively by irrigation [4]. Therefore, prediction of the state of groundwater enhances the effectiveness of water management in the production of crops and especially of cotton. Cotton for the mentioned region is the main plant and occupies more than $60 \%$ of the irrigated area of the Syrdarya river basin [4]. As the research methods defined the water-balance method of the river basin, the method of unspecified filtering and interpolation method of climatic factors, developed by the authors.

The water balance equation in the Chirchik river basin:

$$
Q_{\mathrm{gw}}=W+Q_{\text {Char }+ \text { Ugam }}+Q_{\text {Ohan }}+P+Q_{\text {return }}-Q_{\text {Chinoz }}-Q_{\text {use }}-Q_{\text {syr-darya }}-E T-E
$$

$W$ : water increment of groundwater;

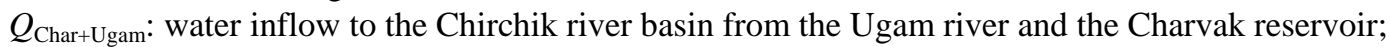

$Q_{\text {ohan }}$ : water inflow to the Chirchik river basin from the Akhangaran river;

$P$ : precipitation;

$Q_{\text {chinaz }}:$ water abstraction in the Chinaz station;

$Q_{\text {use: }}$ water use in the Chirchik river basin;

$E T$ : total amount of transpiration;

$E$ : total amount of soil evaporation;

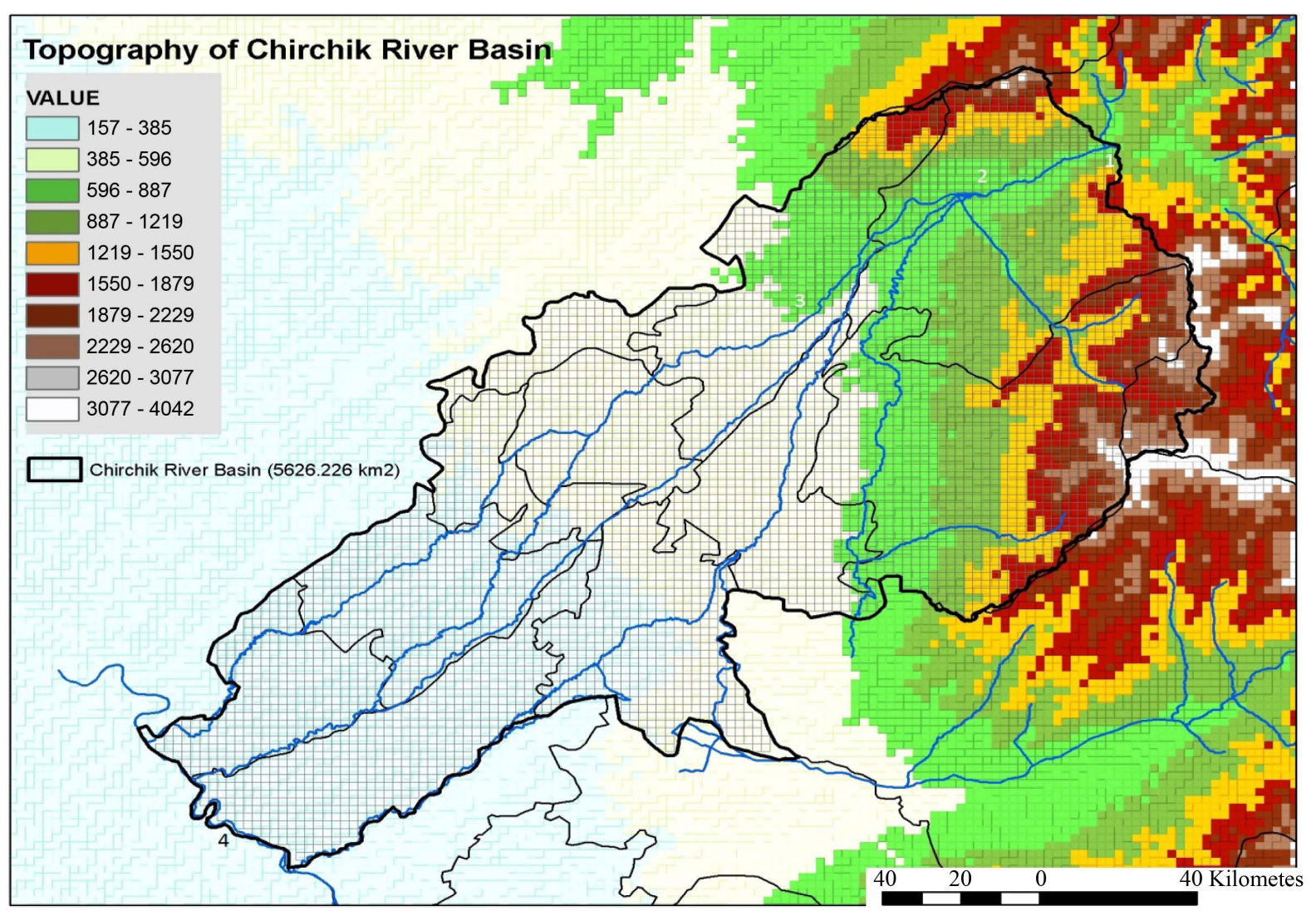

Figure 1. Topography of Chirchik river basin (1—Charvak reservoir; 2-Chirchik river; 3—Bozsuv channel; 4—Syr-Darya river). 
$Q_{\mathrm{gw}}$ : ground water discharge and expenditure;

$Q_{\text {syr-darya: }}$ effluent of groundwater to Syr-Darya river;

$Q_{\text {return }}$ : return water from collectors.

The Richard's equation of unsteady filtration of water:

$$
\frac{\partial \theta}{\partial t}=-\frac{\partial\left[K(h)\left(\frac{\partial h}{\partial z}+1\right)\right]}{\partial z}-S((h))
$$

where $\theta$-volumetric soil moisture; $t$ - time (day); $S(h)$ — the rate of extraction of water by plant roots (evapotranspiration), $\mathrm{m}^{3} / \mathrm{m}^{3}$ day; $h$-pressure of soil moisture (cm of water); $z$-vertical coordinate pointing upwards; $K$ - the coefficient of hydraulic conductivity (hydraulic conductivity), $\mathrm{cm} /$ day [5].

Interpolation method of the climatic data is shown in Figure 2.

The values of the coordinates of hydro-meteorological stations are based on the relative origin to the Tashkent weather station in meters (Figure 3).

\section{Results and Discussions}

Using the parameters of the water balance Chirchik river basin, topographic maps using the program MIKESHE simulation model to get a map of seasonal changes in groundwater levels throughout the basin of Chirchik river (Figure 5).

To establish reliability of the data on changes in groundwater levels were the measured values of the groundwater level according to data on observation wells in the basin with the results obtained by the simulation model (Table 1, Figure 3). Calibration and comparison of the results obtained by natural observation and calculation method of feature points in the basin are shown in Figures 4-6.

In Figures 7-9 the dark lines show the land surface and the red and blue lines- groundwater levels, determined by different methods [7]. As the graphs show similar values to predicted (Table 2) and actual (Table 3) values of groundwater level fluctuations within acceptable RMSE for W06 point is 0.580954, RMSE for W03 point is 0.65943 and RMSE for W09 point is 0.645235 .

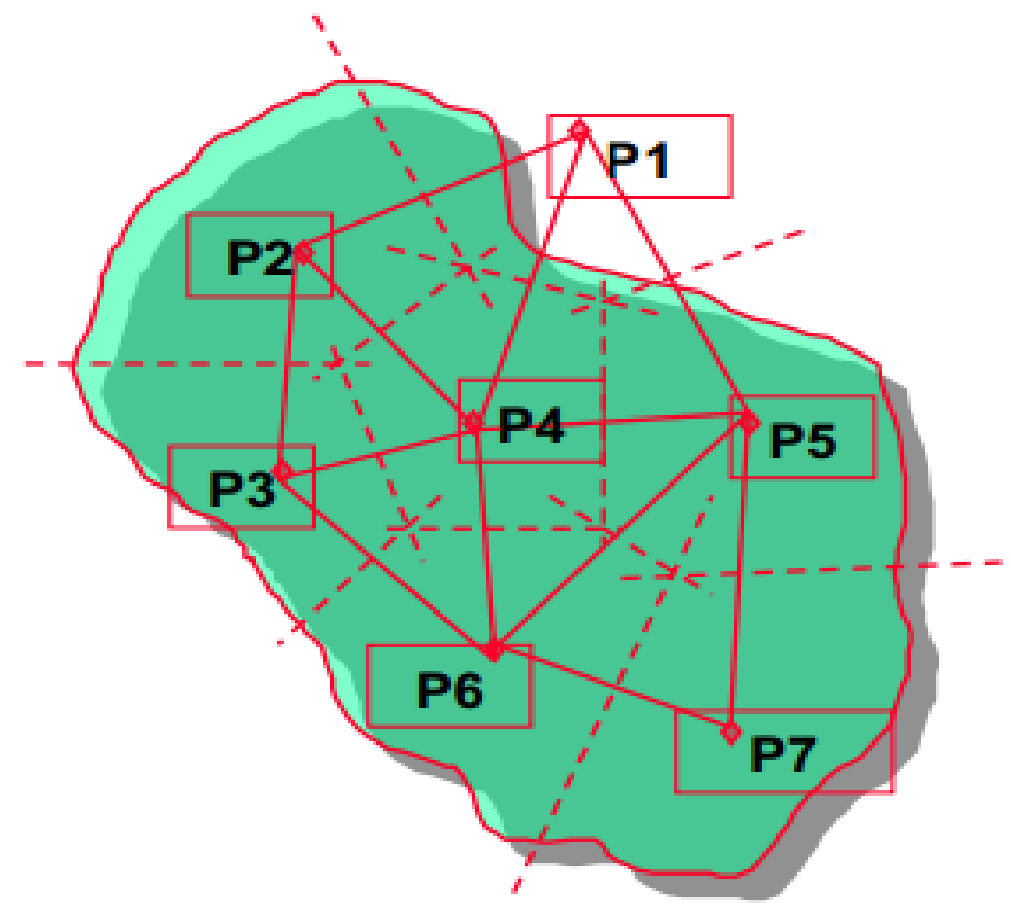

Figure 2. Thiessen polygon method in scheme of creating an interpolation method for establishing climatic factors of the Chirchik river basin [5]. 


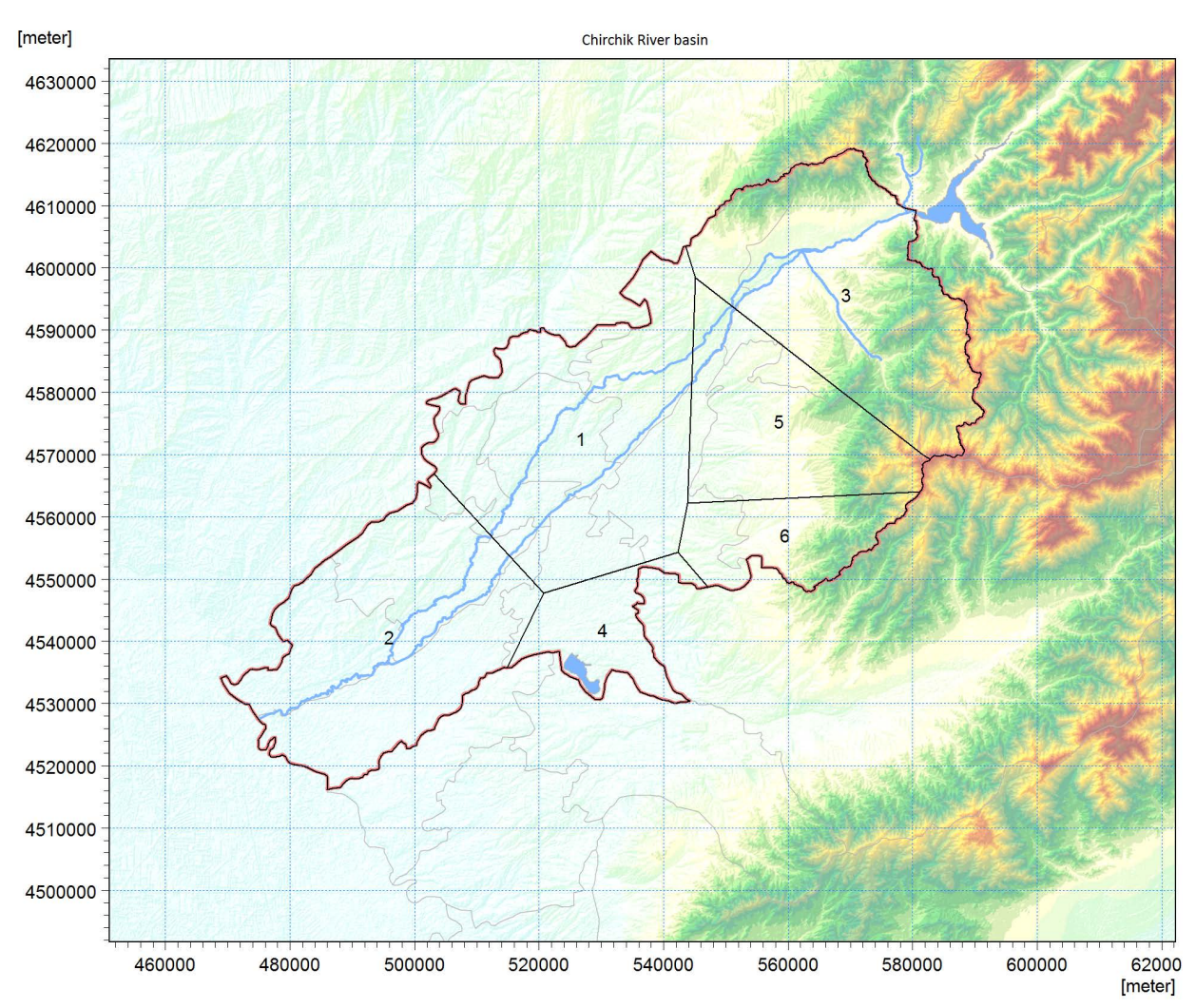

Figure 3. Layout stations in the Chirchik river basin by using Thiessen polygon method in ArcGIS.

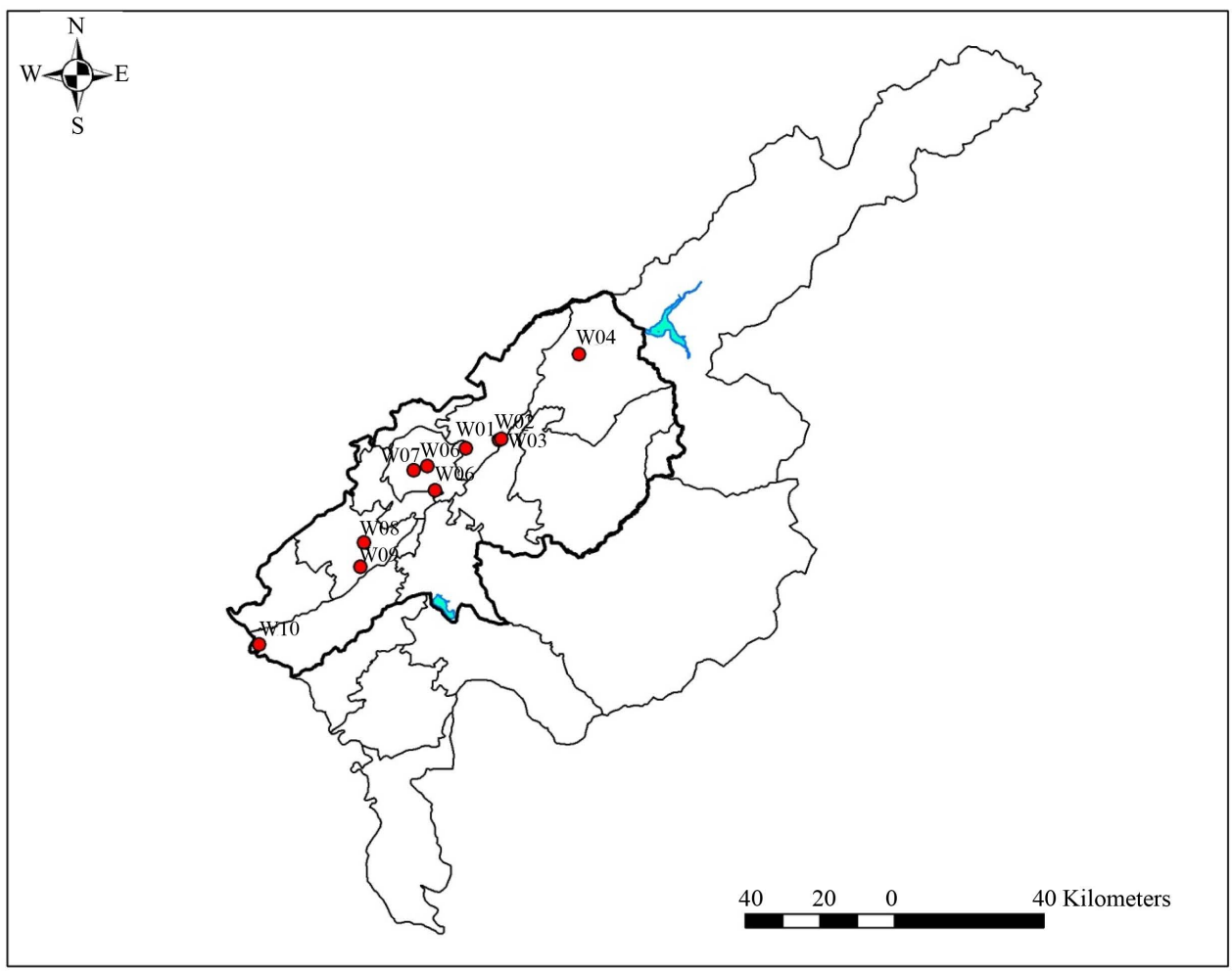

Figure 4. Location network of observation wells. 

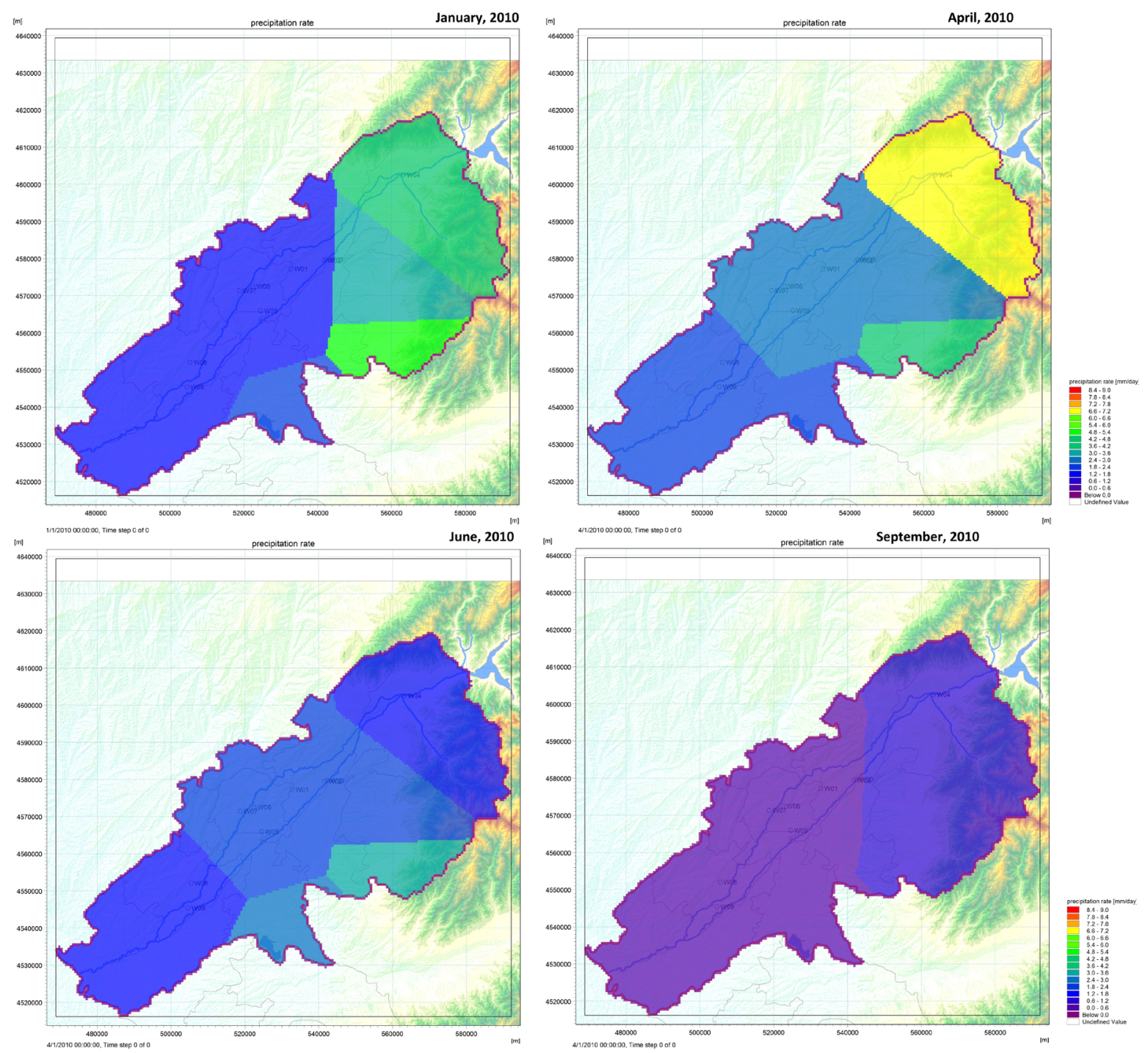

Figure 5. Seasonal changes and distributions of rainfall in the Chirchik river basin in 2010.

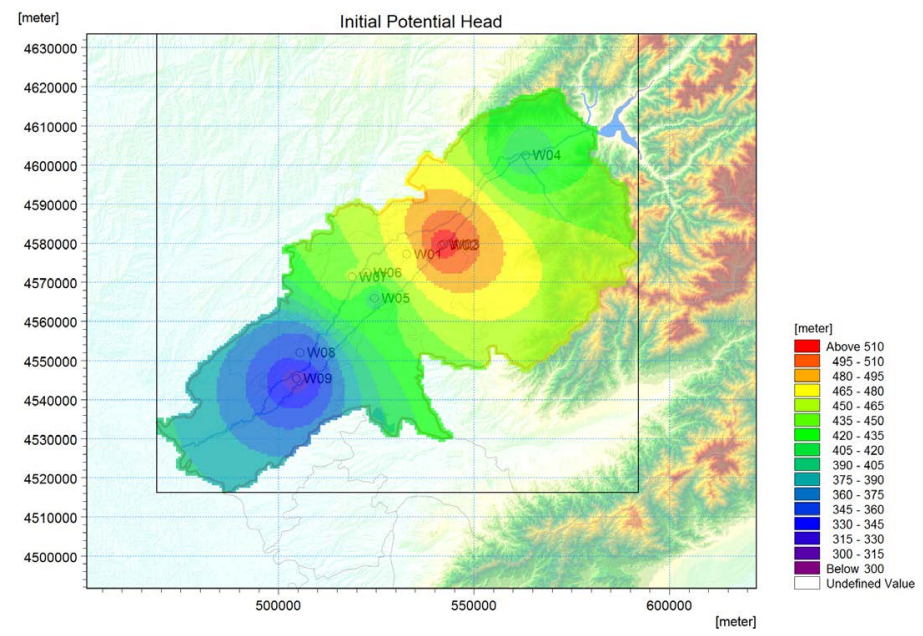

Figure 6. Interpolated ground water level based on observed water levels. 


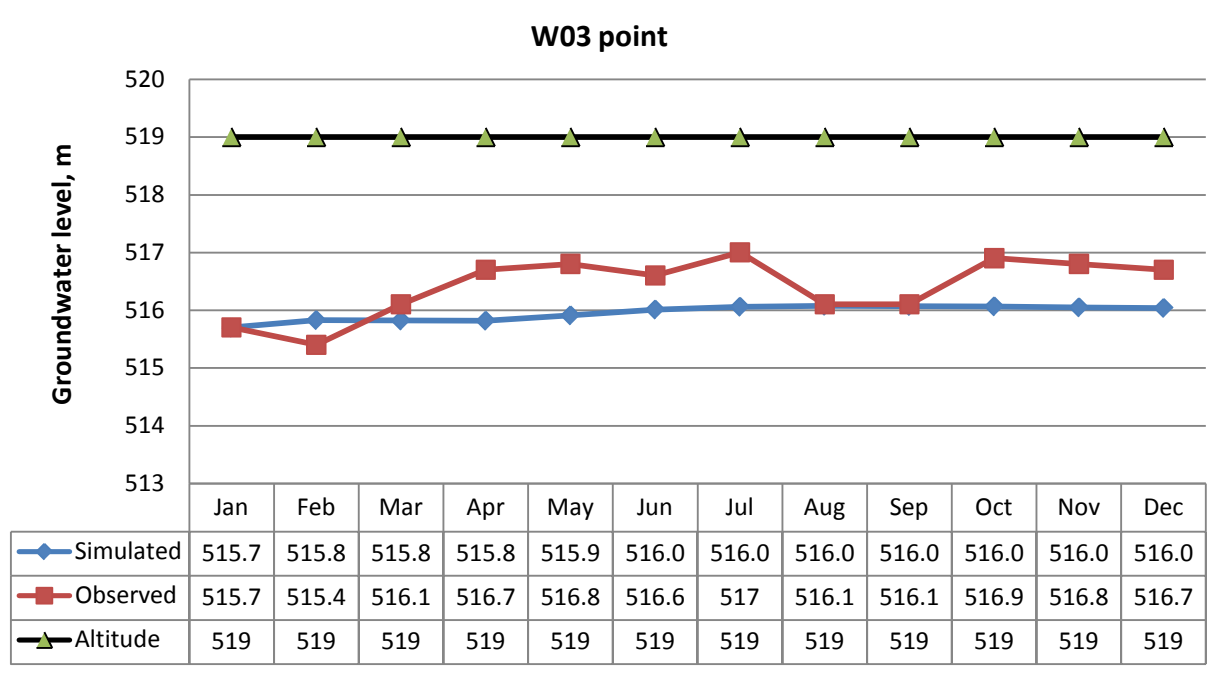

Figure 7. Calibration results of calculation methods with the results of measurements on the well 03.

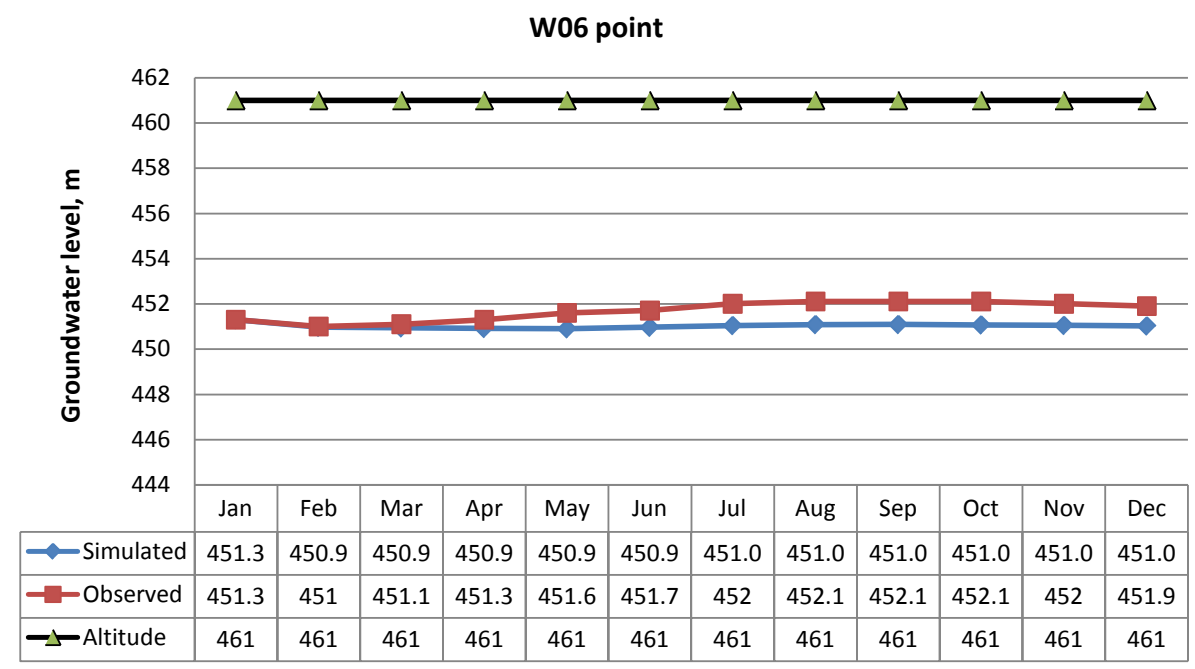

Figure 8. Calibration results of calculation methods with the results of measurements on the well 06.

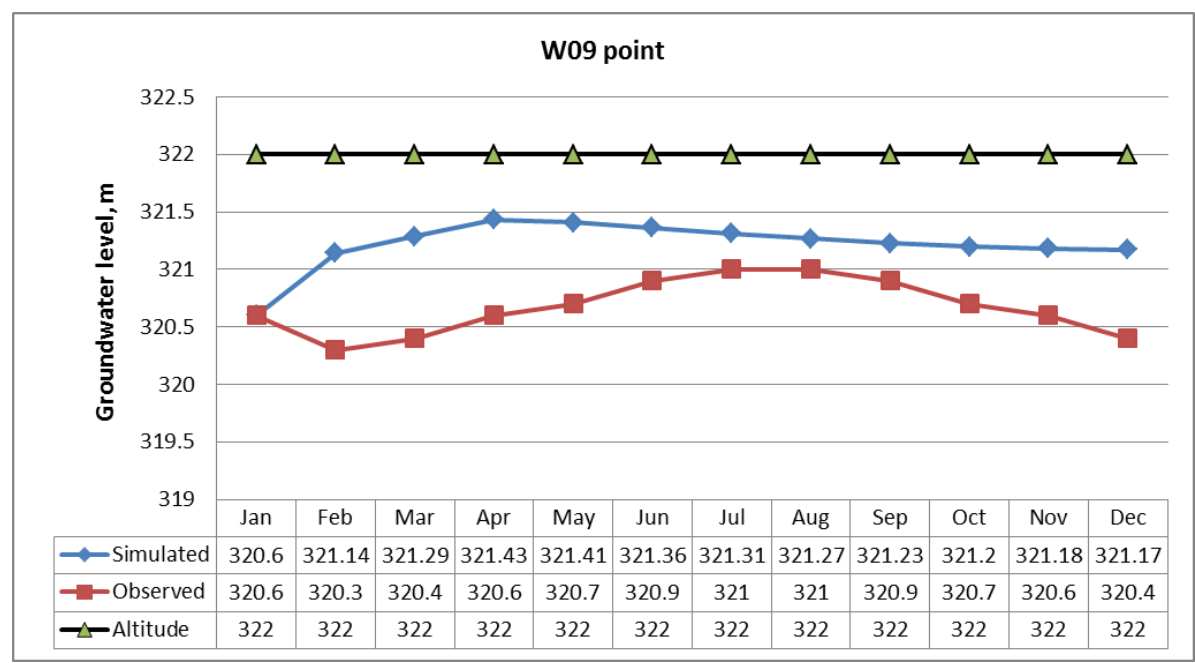

Figure 9. Calibration results of calculation methods with the results of measurements on the well 09. 


\begin{tabular}{|c|c|c|c|c|c|c|c|c|c|}
\hline \multirow[b]{2}{*}{$\begin{array}{l}\text { Deposit and its } \\
\text { resources on the } \\
\text { revaluation, } \mathrm{m}^{3} / \mathrm{s}\end{array}$} & \multirow[b]{2}{*}{$\begin{array}{c}\text { The } \\
\text { calculation } \\
\text { period }\end{array}$} & \multicolumn{2}{|c|}{$\begin{array}{l}\text { The arithmetic mean } \\
\text { of the oscillation } \\
\text { amplitude (m) by: }\end{array}$} & \multirow{2}{*}{$\begin{array}{l}\text { The } \\
\text { coefficient of } \\
\text { water loss } \\
\text { breeds } \\
\text { share of units }\end{array}$} & \multirow[b]{2}{*}{$\begin{array}{l}\text { Deposit } \\
\text { area, } \\
\mathrm{km}^{2}\end{array}$} & \multicolumn{3}{|c|}{$\begin{array}{l}\text { Resources of deposits of } \\
\text { groundwater }\left(\mathrm{m}^{3} / \mathrm{s}\right) \text { for: }\end{array}$} & \multirow{2}{*}{$\begin{array}{l}\text { The value of the } \\
\text { accumulation }(+) \\
\text { consumption }(-) \text { of } \\
\text { groundwater } \\
\text { resources } \\
(3=31,546 \times \\
106 \times \Delta \mathrm{Q}) \text {; } \\
106 \mathrm{~m}^{3} \text { per year }\end{array}$} \\
\hline & & Infiltration & Expenditure & & & Infiltration & Expenditure & $\begin{array}{l}\text { Difference } \\
\text { between } \\
\text { infiltartion } \\
\text { and } \\
\text { expenditure }\end{array}$ & \\
\hline 1 & 2 & 3 & 4 & 5 & 6 & 7 & 8 & 9 & 10 \\
\hline \multirow{2}{*}{$\begin{array}{l}\text { Ahangaran, } \\
22.773\end{array}$} & Previous & 3.32 & -2.83 & \multirow{2}{*}{0.2} & \multirow{2}{*}{1023} & 21.53 & -8.35 & 3.18 & 100.3 \\
\hline & Reported & 2.38 & -2.56 & & & 15.44 & -16.6 & -1.16 & -36.6 \\
\hline \multirow{2}{*}{ Pskent, 2.0} & Previous & 1.34 & -1.29 & \multirow{2}{*}{0.075} & \multirow{2}{*}{688} & 2.19 & -2.11 & 0.08 & 2.52 \\
\hline & Reported & 1.28 & -1.34 & & & 2.09 & -2.19 & -0.10 & -3.15 \\
\hline \multirow{2}{*}{ Chirchik, 38.2} & Previous & 2.23 & 2.48 & 0.25 & \multirow{2}{*}{1949} & 33.44 & 38.3 & -3.86 & -121.77 \\
\hline & Reported & 2.48 & 2.29 & 0.25 & & 38.3 & 35.37 & +2.93 & +92.43 \\
\hline
\end{tabular}

Table 2. Simulated results of the level of groundwater by using MIKE SHE simulation model of river basin balance.

\begin{tabular}{|c|c|c|c|}
\hline Wells & W03 & W06 & W09 \\
\hline Coordinates & $\begin{array}{l}69.50517 \\
41.36778\end{array}$ & $\begin{array}{l}69.26844 \\
41.30378\end{array}$ & $\begin{array}{l}69.05472 \\
41.05992\end{array}$ \\
\hline Altitude & 519 & 461 & 244 \\
\hline \multicolumn{4}{|c|}{ Simulated results } \\
\hline JAN & 515.7 & 451.3 & 320.6 \\
\hline FEB & 515.82 & 450.96 & 321.14 \\
\hline MARCH & 515.82 & 450.93 & 321.28 \\
\hline APRIL & 515.81 & 450.91 & 321.43 \\
\hline MAY & 515.91 & 450.89 & 321.4 \\
\hline JUNE & 516 & 450.96 & 321.36 \\
\hline JULY & 516 & 451.03 & 321.31 \\
\hline AUG & 516 & 451.08 & 321.26 \\
\hline SEPT & 516.1 & 451.08 & 321.22 \\
\hline OCT & 516.06 & 451.06 & 321.19 \\
\hline NOV & 516.05 & 451.04 & 321.18 \\
\hline DEC & 516.03 & 451.02 & 321.17 \\
\hline
\end{tabular}

\section{Conclusion}

As a result, the model developed made it possible to reliably estimate ground water level by using climatic data in the river basin. Taking into consideration that groundwater together with irrigation water is sources of water 
Table 3. Initial data for the assessment of groundwater monitoring wells in 2010 (m) [6].

\begin{tabular}{|c|c|c|c|}
\hline Wells & W03 & W06 & W09 \\
\hline Coordinates & $\begin{array}{l}69.50517 \\
41.36778\end{array}$ & $\begin{array}{l}69.26844 \\
41.30378\end{array}$ & $\begin{array}{l}69.05472 \\
41.05992\end{array}$ \\
\hline Altitude & 519 & 461 & 244 \\
\hline \multicolumn{4}{|c|}{ Observed data } \\
\hline JAN & 515.7 & 451.3 & 320.6 \\
\hline FEB & 515.4 & 451 & 320.5 \\
\hline MARCH & 516.1 & 451.1 & 320.6 \\
\hline APRIL & 516.7 & 451.3 & 320.6 \\
\hline MAY & 516.8 & 451.6 & 320.8 \\
\hline JUNE & 516.9 & 451.7 & 320.8 \\
\hline JULY & 517.0 & 452.0 & 320.8 \\
\hline AUG & 517.1 & 452.1 & 320.7 \\
\hline SEPT & 517.0 & 452.1 & 320.7 \\
\hline OCT & 516.9 & 452.1 & 320.6 \\
\hline NOV & 516.8 & 452.0 & 320.5 \\
\hline DEC & 516.7 & 451.9 & 320.4 \\
\hline
\end{tabular}

use plants, prediction method can effectively manage water resources for irrigation of crops, especially cotton. Forecast for the groundwater level contributes to the adoption of scientific and technical measures to protect the irrigated land from waterlogging and salinity.

\section{References}

[1] Makhmudov, Kh., Mitani, Y. and Kusuda, T. (2015) Interpolation of Climatic Parameters by Using Barycentric Coordinates. World Journal of Environmental Engineering, 3, 1-6.

[2] Petrov, V., Egamberdiev, H., Kholmatzhonov, B. and Alaudinov, T. (2006) Meteorology. NUU, Tashkent, 330.

[3] DHI (2012) MIKESHE User Manual, Volume-2, and Reference Guide.

[4] Makhmudov, Kh. (2012) Integrated River Basin Management in Chirchik River Basin. Master's Thesis, The University of Kitakyushu, Kitakyushu.

[5] DHI (2012) MIKESHE User Manual, Volume-1, and Reference Guide.

[6] The Institute of Groundwater (2010) Report of the GP “Gidroingeo”. The Institute of Groundwater, Tashkent, 74-77.

[7] Phillips, N.A. (1957) A Coordinate System Having Some Special Advantages for Numerical Forecasting. Journal of Meteorology, 14, 184-185. http://dx.doi.org/10.1175/1520-0469(1957)014<0184:ACSHSS>2.0.CO;2 